\title{
Faktor-Faktor Yang Mempengaruhi Kemiskinan di Pulau Sulawesi
}

\author{
Friska Mahmud 1), Fachrudin Zain Olilingo ${ }^{2)}$, Fitri Hadi Yulia Akib ${ }^{3)}$ \\ ${ }^{1)}$ Mahasiswa Fakultas Ekonomi, Universitas Negeri Gorontalo \\ 2),3)Dosen Fakultas Ekonomi, Universitas Negeri Gorontalo \\ friskamahmud24gmail.com
}

\begin{abstract}
The research aims to find our the factors impacting poverty in Sulawesi Island, including unemployment, economic growth, and everage length of school. Data employed are secondary data from Statistics Indonesia from 2015 to 2019 in six provinces. Method used in this research is multiple linear regression analysis of panel data. The research finding indicates that unemployment impacsts poverty positively but insingnificantly, which denotes that every increase in unemployment rate does not always increase poverty rate in Sulawesi Island. Then, the economic growth impacts poverty negatively and significantly, which denotes that every increase in economic growth can reduce the poverty rate in Sulawesi Island. Lastly, the everage length of school impacth poverty negatively and significantly, which denotes that every increase in the everage length of school is followed by reducation in the poverty rate in Sulawesi Island.
\end{abstract}

Keywords: Poverty, Unemployment, Economic Growth, Average Length of school

\section{Pendahuluan}

Indonesia pada saat ini mengalami berbagai permasalahan yang menyangkut hal-hal mengenai kehidupan masyarakat antara lain masalah yang menyangkut kemiskinan. Permasalahan yang timbul dari terjadinya ketidakmerataan hasil pendapatannya (Prasetyoningrum, 2018). Kemiskinan merupakan masalah pembangunan yang dapat terjadi dimana saja,baik di Negara maju maupun Negara berkembang. Sebagai Negara berkembang, kemiskinan merupakan salah satu isu besar di dalam perekonomian Indonesia, seolah- olah menjadi "pekerjaan rumah" yang permasalahan kemiskinan sebenarnya sudah di tempuh dengan berbagai cara, mulai dari program bantuan modal atau uang tunai kepada rakyat miskin sampai program transmigrasi. Tingginya angka kemiskinan disebabkan oleh produksi yang terbatas dan aset produksi yang rendah (Arham dan Hatu, 2020).

Kemiskinan merupakan masalah yang dihadapi oleh seluruh Negara, terutama di Negara sedang berkembang seperti Indonesia. Kemiskinan adalah keterbatasan yang di sandang seseorang, keluarga, sampai 
komunitas, atau bahkan Negara yang menyebabkan ketidaknyamanan dalam kehidupan, terancamnya penegakan hukum dan keadilan serta hilangnya generasi dan suramnya masa depan bangsa dan Negara. Pengertian itu merupakan pengertian secara luas, telah dikatakan kemiskinan terkait dengan ketidaknyamanan dalam hidup. Dalam segala bidang selalu menjadi kaum tersingkir karena tidak dapat menyamakan kondisi dengan kondisi masyarakat masyarakat sekitarnya. (Gamal, 2016).

Tingginya jumlah dan presentase penduduk miskin disuatu daerah tentu saja akan menjadi beban pembangunan, sehingga peran pemerintah dalam mengatasinya pun akan semakin membesar. Alokasi dana APBN/APBD untuk program-program penanggulangan kemiskinan, dapat dikatakan berhasil apabila jumlah dan presentase penduduk miskin turun atau bahkan tidak ada. Namun, fakta yang mengindikasikan bahwa kebijakan penanggulangan kemiskinan senantiasa menjadi hal yang perlu dicermati dan dikaji ulang khususnya dalam penyusunan dan penerapan strategi dan program pengentasan kemiskinan yang dijalankan oleh pemerintah. Kemiskinan beberapa wilayah di Indonesia masih menjadi masalah yang sangat serius terutama beberapa provinsi di Pulau Sulawesi.

Secara administratif pulau Sulawesi terdiri dari 6 provinsi yaitu provinsi Sulawesi Utara, Sulawesi Tengah, Sulawesi Selatan, Sulawesi Barat, Sulawesi Tenggara dan Provinsi Gorontalo. Tingginya angka kemiskinan di beberapa daerah ini akan sangat mempengaruhi kinerja perekonomian. Seperti data yang dilansir dari Badan Pusat Statistik masing-masing provinsi di Pulau Sulawesi disajikan dalam grafik berikut.

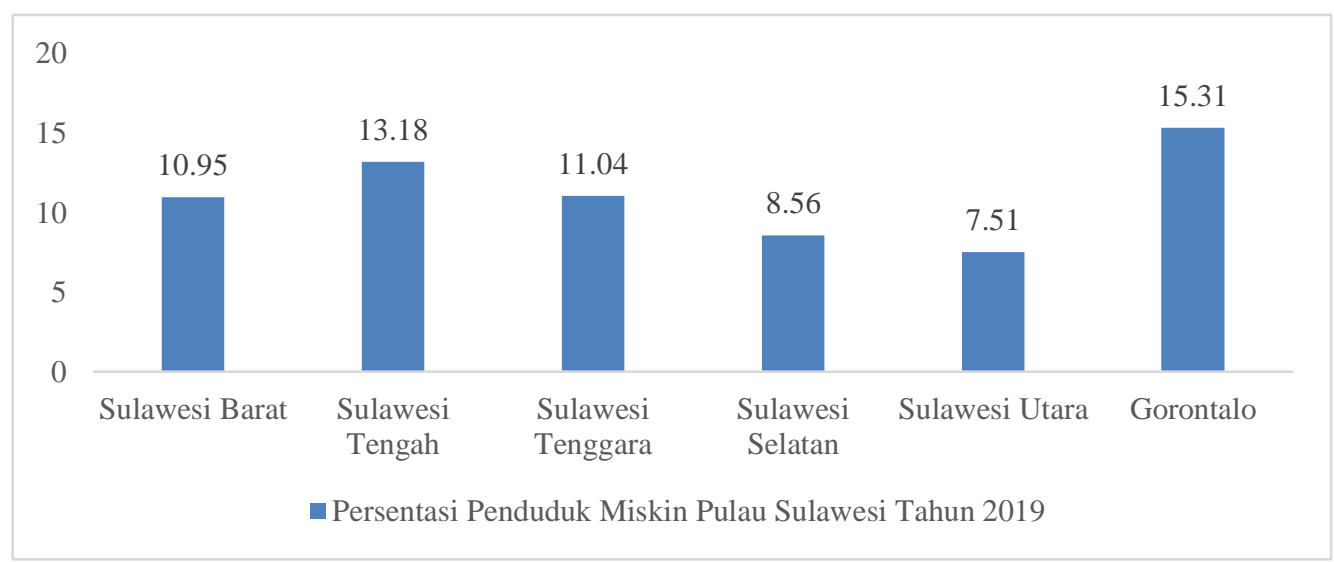

Sumber: Badan Pusat Statistik 2020

\section{Gambar 1.1}

\section{Grafik Persentasi Penduduk Miskin Pulau Sulawesi Tahun 2019}

Dari grafik diatas dapat dilihat bahwa secara rata-rata kemiskinan di pulau Sulawesi masih tinggi. Provinsi Gorontalo menjadi daerah yang memiliki tingkat kemiskinan paling tinggi yaitu sebesar 15.31 persen.
Kemudian provinsi Sulawesi tengah dengan angka kemiskinan sebesar 13.18 persen. Selanjutnya diikuti oleh provinsi Sulawesi Tenggara sebesar 11.04 persen. Kemudian pada provinsi Sulawesi Selatan hanya sebesar 8,56 dan 
juga provinsi Sulawesi Utara menjadi daerah yang memiliki persentasi penduduk miskin paling sedikit dibanding daerah lainnya di Pulau Sulawesi yaitu hanya mencapai angka sebesar 7.51 persen.

Tingginya presentase penduduk miskin disuatu wilayah akan berpengaruh pada rendahnya daya beli masyarakat di wilayah tersebut. Hal ini karena umumnya pendapatan penduduk miskin tersebut rendah sehingga dari segi pendapatan perkapita juga rendah, apalagi rata-rata jumlah anggota rumah tangga penduduk miskin umumnya lebih banyak dari rumah tangga penduduk tidak miskin sehingga rata-rata pendapatan perkapita penduduk tersebut relative lebih rendah, keadaan ini akan lebih parah lagi jika tingkat pengangguran diwilayah tersebut juga tinggi.

Pengangguran merupakan masalah bagi semua Negara di dunia. Tingkat pengangguran yang tinggi akan menganggu stabilitas nasional Negara. Sehingga setiap Negara berusaha untuk mempertahankan tingkat pengangguran pada tingkat yang wajar.
Masalah pengangguran selalu menjadi permasalahan yang sulit terpecahkan disetiap Negara. Sebab jumlah penduduk yang bertambah semakin besar tiap tahunnya, akan menyebabkan meningkatnya jumlah orang pencari kerja, dan seiring itu tenaga kerja juga akan bertambah. Jika tenaga kerja tidak terserap ke dalam lapangan pekerjaan maka mereka akan tergolong ke dalam orang yang menganggur (Aziz Septianti 2016). Pengangguran merupakan salah satu factor penyebab kemiskinan di Indonesia. Hal ini dapat dilihat dari banyaknya data pengangguran yang ada. Berikut data tingkat pengangguran terbuka di Indonesia.Hampir seluruh daerah yang ada di imdonesia tingkat penganggurannya masih tinggi tidak terkecuali pulau Sulawesi.

Tingkat pengangguran tertinggi di Indonesia masih tinggi dan juga mengalami peningkatan dari bulan Maret (semester 1) sebesar 5.01 persen hingga pada bulan September (semester 2) sebesar 5.28). Berikut Grafik data tingkat pengangguran terbuka di Indonesia dan pulau Sulawesi pada tahun 2019.

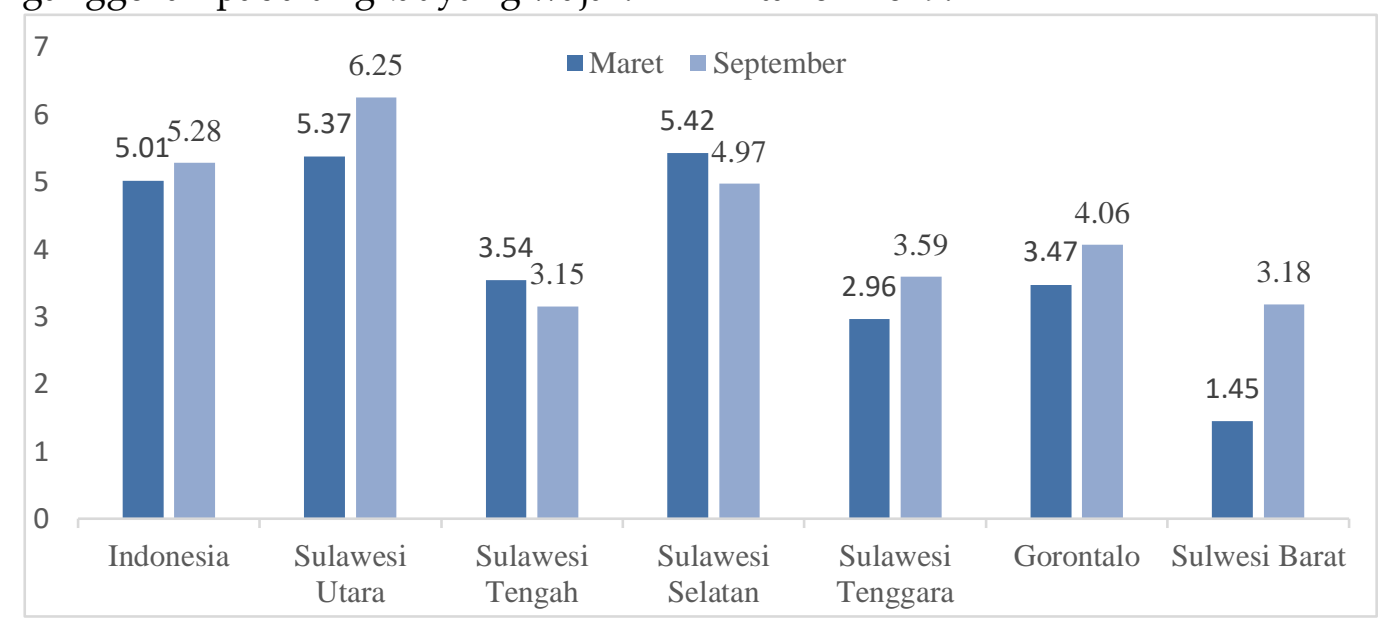

Grafik 1.2 (Sumber: Badan Pusat Statistik, 2020)

Data Tingkat Pengangguran Terbuka Di Pulau Sulawesi Tahun 2019 
Pembangunan suatu daerah merupakan suatu upaya meningkatkan daya saing daerah dalam menghadapi persaingan global. Adanya tuntutan tersebut berdampak pada setiap daerah untuk mempercepat pembangunan ekonomi daerah berdasarkan potensi sektor unggulan yang dimiliki oleh masing-masing daerah (Santoso, Olilingo 2019). Pertumbuhan Ekonomi menjadi salah satu indikator untuk melihat kinerja perekonomian, baik di tingkat nasional maupun regional. Pertumbuhan ekonomi sangat ditentukan oleh sumber daya manusia (Muda, dkk 2019). Pertumbuhan ekonomi juga merupakan salah satu factor yang yang dapat mempengaruhi kemiskinan. Ukuran umum yang digunakan untuk mengukur laju pertumbuhan ekonomi adalah Produk Domestik Bruto untuk Skala Provinsi atau Kabupaten/Kota. Provinsi di Pulau Sulawesi juga berpatokan pada Produk Domestik Regional Bruto untuk mengukur pertumbuhan ekonomi. Berikut data Pertumbuhan Ekonomi Provinsi di Indonesai dan Pulau Sulawesi.

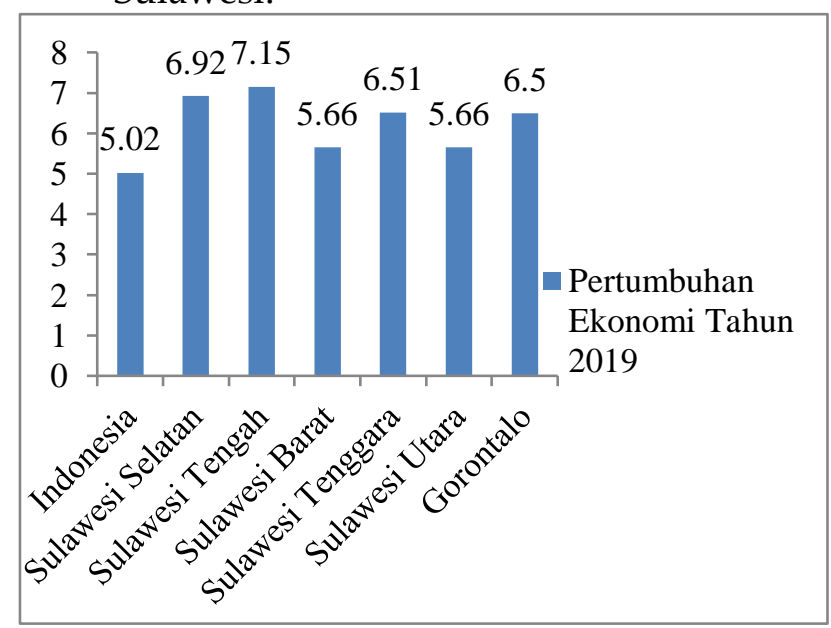

Grafik 1.3 (Sumber: BPS 2020)

Pertumbuhan Ekonomi Indonesia dan Provinsi Di Pulau Sulawesi, 2019
Berdasarkan grafik di atas dapat disimpulkan bahwa pertumbuhan ekonomi di Indonesia sebesar 5.02 persen. Sedangkan pertumbuhan ekonomi beberapa Provinsi di Pulau Sulawesi rata-rata lebih tinggi dibandingkan dengan pertumbuhan ekonomi Indonesia. Provinsi Sulawesi Selatan menunjukkan angka pertumbuhan ekonomi sebesar 6,92\%. Sulawesi Tengah menujukkan angka pertumbuhan ekonomi sebesar 7,15\%. Sulawesi Barat menunjukkan angka pertumbuhan ekonomi sebesar 5,66\%. Sulawesi Tenggara menunjukkan angka pertumbuhan ekonomi sebesar 6,51\%. Sulawesi utara menunjukkan angka pertumbuhan ekonomi sebesar 5,66\%. Gorontalo menunjukkan angka pertumbuhan ekonomi sebesar 6,5\%. Dari semua wilayah yang paling tinggi pertumbuhan ekonominya adalah Provinsi Sulawesi tengah.

Selain masalah pengangguran dan juga tingkat pertumbuhan ekonomi yang masih rendah, tingkat pendidikan penduduk juga perlu diamati, dimana tingkat pendidikan merupakan salah satu elemen yang sangat penting untuk mengukur kualitas penduduk disuatu wilayah tertentu. Tingkat pendidikan yang tinggi akan berpengaruh terhadap kesejahteraan seseorang dan juga dapat meningkatkan produktivitas seseorang. Seperti yang dikatakan oleh (Arham dan Dai, 2019) bahwa produktivitas merupakan dampak dari meningkatnya pembentukan modal manusia, di mana variabel pendidikan sangat menentukan di dalamnya.

Pendidikan dalam hal ini diukur dengan tingkat rata-rata lama sekolah. Rata-rata lama sekolah adalah rata-rata jumlah tahun yang dihabiskan oleh 
penduduk berusia 15 tahun ke atas untuk menempuh semua jenis pendidikan yang pernah dijalani (Sirusa BPS, 2020). Pada saat ini angka rata-rata lama sekolah di pulau Sulawesi itu sebagian besar masih tergolong sangat rendah. Dapat kita lihat pada grafik berikut.

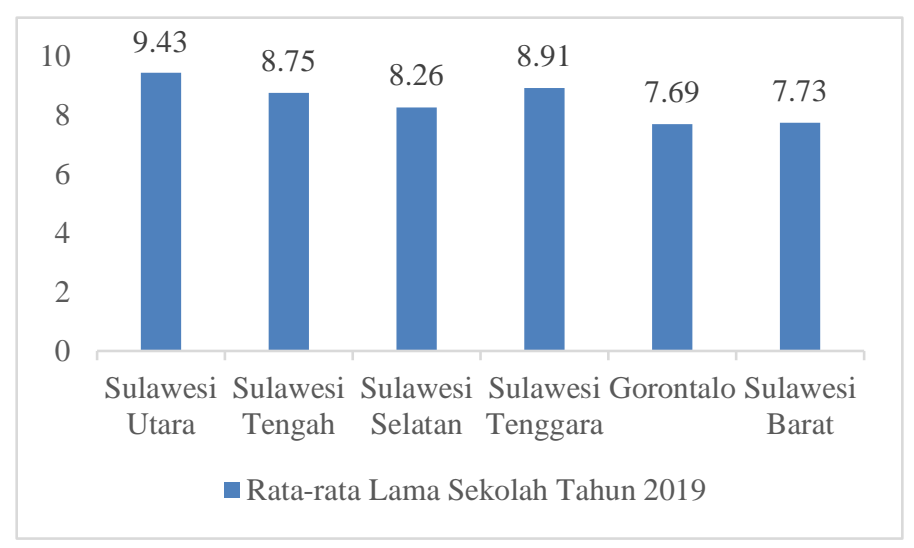

Gambar 1.4 (Sumber: BPS, 2020)

Grafik Data Rata-rata Lama Sekolah Pulau Sulawesi Tahun 2019

Dari grafik diatas dapat dilihat bahwa rata-rata lama sekolah di pulau Sulawesi berada dibawah dari 10 tahun. Sulawesi utara memiliki angka rata-rata lama sekolah paling tinggi dibanding daerah lain yaitu sebesar 9.43. kemudian diikuti oleh provinsi Sulawesi Tenggara dengan angka ratarata lama sekolah sebesar 8.91. kemudian ada provinsi Sulawesi Tengah dengan angka rata-rata lama sekolah sebesar 8.75 dan Sulawesi Selatan sebesar 8.26. diurutan paling bawah ada dua daerah yang memiliki tingkat rata-rata lama sekolah dibawah dari 8 tahun yaitu provinsi Sulawesi Barat dengan tingkat rata-rata lama sekolah sebesar 7.73 dan Provinsi Gorontalo yang paling rendah di pulau Sulawesi yaitu sebesar 7.69. Hal ini menandakan bahwa tingkat pendidikan di pulau Sulawesi yang dilihat dari ratarata lama sekolah masih tergolong rendah hanya berkisar diantara 7 sampai 9 tahun. Masalah pendidikan ini perlu diperhatikan lagi oleh pemerintah maupun masyarakat dimana pendidikan ini sangat berpengaruh terhadap tingkat kemiskinan penduduk di pulau Sulawesi

Fenomena kemiskinan merupakan masalah bagi Negara berkembang seperti Indonesia, khususnya di pulau Sulawesi. Tingginya angka pengangguran, juga rendahnya tingkat pendidikan penduduk menjadi faktor utama yang menyebabkan tingginya angka kemiskinan di pulau Sulawesi. Berdasarkan fenomena ini maka penulis tertarik melakukan penelitian tentang "Faktor-Faktor Yang Mempengaruhi Kemiskinan di Pulau Sulawesi".

\section{Tinjauan Pustaka}

Teori Kemiskinan

Kemiskinan merupakan masalah yang dihadapi oleh seluruh Negara, terutama di Negara sedang berkembang seperti Indonesia. Kemiskinan adalah keterbatasan yang di sandang seseorang, keluarga, komunitas atau bahkan Negara yang menyebabkan ketidaknyamanan dalam kehidupan terancamnya penegakan hukum dan keadilan serta hilangnya generasi dan suramya masa depan bangsa dan Negara. Pengertian itu merupakan pengertian secara luas, elah dikatakan kemiskinan terkait dengan ketidaknyamanan dalam hidup. Dalam segala bidang selalu menjadi kaum tersingkir karena tidak dapat menyamakan kondisi dengan kondisi 
mayarakat sekitarnya. (Gamal Abdul, 2016)

Menurut BPS bahwa kemiskinan adalah ketidakmampuan individu dalam memenuhi kebutuhan dasar minimal untuk hidup layak (baik makanan maupun nonmakanan). Garis kemiskinan yang ditetapkan oleh BPS adalah jumah pengeluaran yang dibutuhkan oleh setiap individu untuk dapat memenuhi kebutuhan makanan setara dengan 2100 kalori per orang per hari dan kebutuhan nonmakanan yang terdiri dari perumahan ,pakaian,keehatan, pendidikan, transportasi, serta aneka barang dan jasa lainnya.

Pada dasarnya definisi kemiskinan dapat dilihat dari dua sisi, yaitu:

a) kemiskinan absolute adalah kemiskinan yang dikaitkan dengan perkiraan tingkat pendapatan dan kebutuhan yang dibatasi pada kebutuhan pokok atau kebutuhan dasar minimum yang memungkinkan seseorang untuk hidup secara layak. Dengan demikian kemiskinan diukur dengan membandingkan tingkat pendapatan orang dengan tingkat pendaptan yang dibutuhkan untuk memperoleh kebutuhan dasarnya yakni makanan, pakaian dan perumahan agar dapat menjamin kelangsunagn hidupnya.

b) Kemiskinan realif adalah kemiskinan dilihat dari aspek ketimpangan social, karena ada orang yang sudah dapat memenuhi kebutuhan dasar minumnya tetapi masih jauh lebih rendah dibanding masyarakat sekitarnya (lingkungannya). Semakin besar ketimpangan antara tingkat penghidupan golongan atas dan golongan bawah maka akan semkin besar pula jumlah penduduk yang dapat di kategorikan miskin, sehingga kemiskinan relatif erat hubungannya dengan masalah distribusi pendapatan. (Tisniwati,2012).

Menurut Sartika (2016) pada dasarnya kemiskinan diidentifikasikan dengan taraf hidup yang rendah, dapat diartikan sebagai suatu keadaan di mana penghidupan penduduk ditandai serba kekurangan akan kebutuhan pokok. Pendapat tersebut mempunyai penekanan bahwa karakteristik yang ada di daerah perkampungan dapat dilihat dari kondisi perumahan orangorangnya dan ketersediaan sarana/prasarana umum dibutuhkan oleh masyarakat. Dalam proses pembangunan suatu Negara ada tiga macam kemiskinan antara lain:

a. Miskin karena miskin, kemiskinan ini disebabkan kemiskinan yang merupakan terolahnya potensi ekonomi dan seterusnya.

b. Kemiskinan yang sebenarnya tidak perlu terjadi di tengah-tengah kelimpahan, kemiskinan yang disebabkan oleh buruknya daya beli dan system yang berlaku.

c. Kemiskinan yang disebabkan karena tidak meratanya serta buruknya pendistribusian produk nasional total (syahrir, 1986)

Kemiskinan dapat disebabkan oleh berbagai hal. Sharp (1996) mencoba mengidentifikasi penyebab kemiskinan dipanndag dari sisi ekonomi:

a) Secara makro, kemikinan muncul karena adanya ketidaksamaan pola kepemilikan sumber daya yang menimbulkan distribusi pendapatan yang timpang. Penduduk miskin hanya memiliki 
sumber daya dalam jumlah terbatas dan kualitasnya rendah.

b) Kemiskinan muncul akibat perbedaan dalam kualitas sumber daya manusia. Kualitas sumber daya manusia yang rendah berarti produktivitasnya rendah, yang pada gilirannya upahnya rendah. Rendahnya kualitas sumber daya manusia ini karena rendahnya pendidikan, nasib yang kurang beruntung, adanya diskriminasi, atau karena keturunan.

c) Kemiskinan muncul akibat perbedaan akses dalam modal.

Persentase penduduk miskin (Head Count Index/ P0) adalah persentase penduduk yang berada dibawah Garis Kemiskinan (GK). Persentase penduduk miskin yang tinggi menunjukkan bahwa tingkat kemiskinan disuatu wilayah juga tinggi (Badan Pusat Statistik, 2020).

$$
P_{a}=\frac{1}{n} \sum_{i=1}^{q}\left[\frac{z-y_{i}}{z}\right]^{\alpha}
$$

Dimana:

$$
\begin{array}{ll}
\begin{array}{ll}
\alpha \\
\mathrm{z}
\end{array} & =0 \\
\mathrm{yi} & =\text { Rata-rata Pengeluaran } \\
& \text { Perkapita sebulan penduduk } \\
& \text { yang berada dibawah garis } \\
& \text { kemiskinan }(\mathrm{i}=1,2,3, \ldots, \mathrm{q}), \mathrm{yi}< \\
\mathrm{z} & \\
\mathrm{q} \quad \text { Banyaknya penduduk yang } \\
\text { berada dibawah } \\
\text { kemiskinan. garis } \\
\text { = Jumlah penduduk. } \\
\text { Indeks Kedalaman Kemiskinan } \\
\text { (Poverty Gap Index/ P1), merupakan } \\
\text { ukuran rata-rata kesenjangan } \\
\text { pengeluaran masing-masing penduduk } \\
\text { miskin terhadap garis kemiskinan. }
\end{array}
$$

Semakin tinggi nilai indeks, semakin jauh rata-rata pengeluaran pesuduk dari garis kemiskinan. Penurunan nilai indeks kedalaman kemiskinan mengindikasikan bahwa rata-rata pengeluaran penduduk miskin cenderung makin mendekati garis kemiskinan dan ketimpangan pengeluaran penduduk miskin juga semakin menyempit (Badan Pusat Statistik, 2020).

$$
P_{\alpha}=\frac{1}{n} \sum_{i=1}^{q}\left[\frac{z-y_{i}}{z}\right]^{a}
$$

Dimana:

$$
\begin{array}{ll}
\alpha & =1 \\
\mathrm{z} & =\text { Garis Kemiskinan } \\
\mathrm{yi} & =\text { Rata-rata Pengeluaran } \\
& \text { Perkapita sebulan penduduk } \\
& \text { yang berada dibawah garis } \\
& \text { kemiskinan }(\mathrm{i}=1,2,3, \ldots, \mathrm{q}), \mathrm{yi}< \\
& \mathrm{z} \\
\mathrm{q} \quad \text { Banyaknya penduduk yang } \\
\\
\quad \text { berada dibawah } \\
\text { kemiskinan. } \\
\mathrm{n} \quad \text { Jumlah penduduk. } \\
\\
\text { Indeks Keparahan Kemiskinan }
\end{array}
$$
(Proverty Severity Index/ P2) memberikan gambaran mengenai penyebaran pengeluaran diantara penduduk miskin. Semakin tinggi nilai indeks, semakin tinggi ketimpangan pengeluaran diantara penduduk miskin.

$$
P_{\alpha}=\frac{1}{n} \sum_{i=1}^{q}\left[\frac{z-y_{i}}{z}\right]^{\alpha}
$$

Dimana:

$$
\begin{array}{ll}
\alpha & =2 \\
\mathrm{z} & =\text { Garis Kemiskinan } \\
\text { yi } & =\text { Rata-rata Pengeluaran } \\
& \text { Perkapita sebulan penduduk } \\
& \text { yang berada dibawah garis }
\end{array}
$$


kemiskinan $(\mathrm{i}=1,2,3, \ldots, \mathrm{q})$, yi $<$ $\mathrm{z}$

$\mathrm{q}=$ Banyaknya penduduk yang berada dibawah garis kemiskinan.

$\mathrm{n} \quad=$ Jumlah penduduk.

\section{Pengangguran}

Menurut Badan Pusat Statitik (BPS) dalam indikator ketenagakerjaan pengangguran merupakan penduduk yang tidak bekerja tetapi sedang mencari pekerjaan atau sedang memprsiapkan suatu usaha baru atau penduduk yang tidak mencari pekerjaan karena sudah diterima bekerja tetapi belum mulai bekerja.

Pengangguran (unemployment) merupakan kenyataan yang dihadapi tidak saja oleh Negara -negara sedang berkembang (developing countries), akan tetapi juga oleh Negara-negara yang sudah maju (developed countries). Secara umum, penganggura didefinisikan sebagai suatu keadaan dimana seseorang yang tergolong dalam kategori angkatan kerja (labe force) tidak memiliki pekerjaan dan secara aktif sedang mencari pekerjaan. Seorang yang tidak bekerja, tetapi secara aktif sedang mencari pekerjaan tidak dapat digolongkan sebagai penganggur (Mawardi, 2016).

Tingkat pengangguran dapat dihitung dengan cara mmembandingkan jumlah penganggura dengan jumlah angkatan kerja yang dinyatakan dalam persen. Ketiadaan pendapatan menyebabkan penganggur harus mengurangi pengeluaran konsumsmnya yang menyebabkan menurunya tingkat kemakmuran dan kesejahteraan. Pengangguran yang berkempanjangan juga dapat mnimbulkan efek psikologis yang buruk terhadap penganggur dan keluarganya. Tingkat pengangguran yang terlalu tinggi juga dapat menyebabkan kekacauan politik, keamanan dan social sehingga menganggu pertumbuhan dan pembangunan ekonomi. Akibat jangka panjang adalah menurnunya GNP pendapatan per kapita suatu Negara. Adapun jenis penganguran dapat dibedakan berdasarkan jam kerja yaitu:

1) Pengangguran terselubung adalah tenaga kerja dapat dikatakan sebagai pengangguran terselubung apabila bekerja kurang dari 7 jam dalam sehari.

2) Setengah menganggur adaah tenaga kerja yang tidak bekerja secara optimal karena tidak ada lapangan pekerjaan, biasanya tenaga kerja setengah menganggur ini merupakan tenaga kerja yang bekerja kurang dari 35 jam selama seminggu.

3) Pengangguran terbuka adalah tenaga kerja yang sungguhsungguh tidak mempunyai pekerjaan. Pengangguran jenis ini cukup banyak karena memang belum mendapat pekerjaan, padahal telah berusaha secara maksimal (Prayuda, 2015).

\section{Pertumbuhan Ekonomi}

Menurut Sukirno pertumbuhan ekonomi dapat didefinisikan sebagai perkembangan kegiatan dalam perekonomian yang menyebabkan barang dan jasa yang diproduksikan dalam masyarakat bertambah. Masalah pertumbuhan 
ekonomi dapat dipandang sebagai masalah makro ekonomi dalam jangka panjang. Dari satu periode ke periode lainnya kemampuan suatu negara untuk menghasilkan barang dan jasa akan meningkat. Kemampuan yang meningkat ini akan disebabkan karena faktor-faktor produksi akan selalu mengalami pertambahan dalam jumlah dan kualitasnya.

\section{Rata-rata Lama Sekolah}

Rata-rata lama sekolah (RLS) adalah rata-rata jumlah tahun yang telah diselesaikan oleh penduduk pada seluruh jenjang pendidikan formal yang pernah dijalani (Hadi, 2019). Penduduk yang dihitung dalam rata-rata lama sekolah adalah penduduk usia 15 tahun keatas. Rata-rata lama sekolah dapat digunakan untuk mengetahui kualitas oendidikan masyarakat dalam sautu wilayah (Sirusa BPS, 2020).

Dalam mencari nilai rata-rata lama sekolah, Badan Pusat Statistik melalui Sirusa merilis konsep Rata-rata Lama Sekolah yaitu sebagai berikut:

$$
R L S=\frac{1}{n} \times \sum_{i=1}^{n} x_{i}
$$

Dimana:

RLS = Rata-rata lama sekolah penduduk usia 25 tahun ke atas

$$
\mathrm{Xi}=\text { Lama sekolah }
$$

penduduk ke-I yang berusia 25 tahun

$\mathrm{N} \quad=$ Jumlah Penduduk usia

\section{5 tahun ke atas}

\section{Kerangka Berpikir}

Suatu bentuk kerangka pikir yang dapat digunakan sebagai pendekatan dalam memecahkan masalah. Dalam penelitian ini akan di teliti Faktor-faktor yang mempengaruhi Kemiskinan di Pulau Sulawesi. Kemiskinan masih menjadi momok bagi tiap daerah di Indonesia, tidak terkecuali Provinsi-Provinsi yang ada di
Pulau Sulawesi. Masih tingginya angka pengangguran, pertumbuhan ekonomi yang tiap tahunnya hanya mengandalkan sektor unggulan yaitu sektor pertanian, dan rata-rata lama sekolah yang masih tinggi, ini merupakan faktor-faktor utama penyebab kemiskinan di Pulau Sulawesi. Berdasarkan fenomena tersebut dan juga mengacu pada teoriteori yang telah diuraikan sebelumnya maka secara garis besar penulis akan melihat hubungan antara kemiskinan dan beberapa faktor penyebabnya. Untuk lebih jelasnya, alur kerangka pikir akan disajikan pada bagan berikut ini.

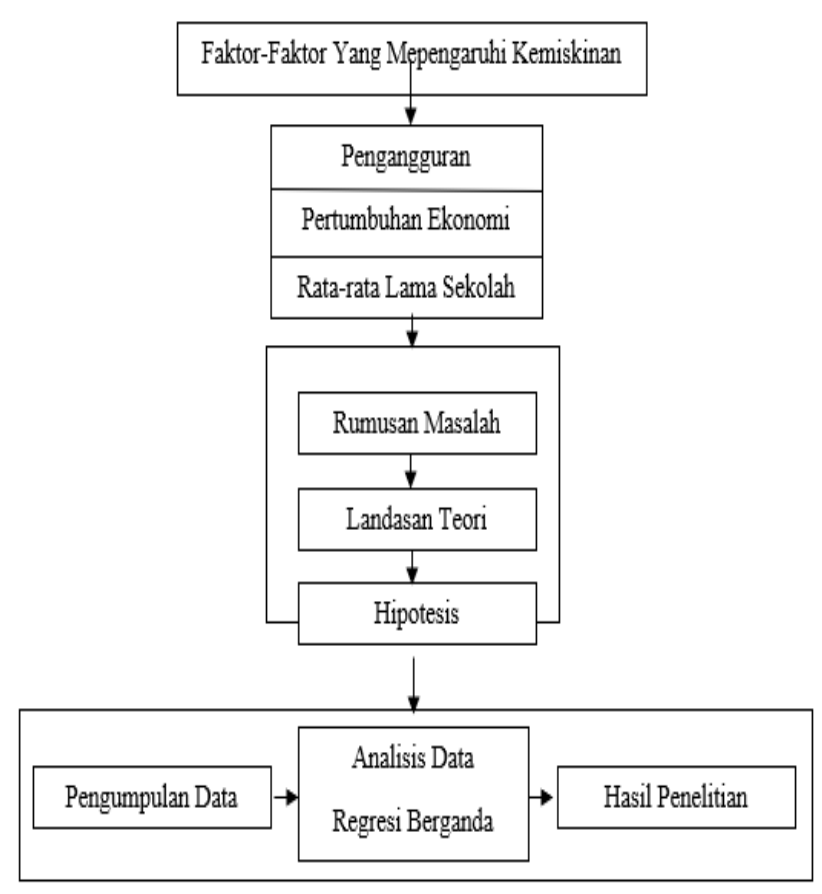

\section{Metode Penelitian}

Penelitian ini dilaksanakan di Pulau Sulawesi yang didalamnya terbagi atas 6 (enam) Provinsi. Pemilihan Kawasan Teluk Tomini didasarkan pada pertimbangan bahwa tingkat kemiskinan di Pulau Sulawesi masih tinggi. Dengan pertimbangan tersebut maka penulis tertarik meneliti 
tentang faktor-faktor yang mempengaruhi kemiskinan di Pulau Sulawesi.

Dalam melakukan penelitian ini penulis menggunakan pendekatan kuantitatif. Menurut Sugiyono (2012) Penelitian kuantitatif adalah metode penelitia yang berlandaskan pada filsafat positifisme, digunakan untuk meneliti pada populasi atau sampel tertenu, pengumpulan data menggunakan instrument penelitian, analisis data, bersifat kuantitatif/statisitk, dengan tujuan untuk menguji hipotesis yang ditetapkan.

Sumber data yang digunakan dalam penelitian ini adalah data sekunder. Data sekunder adalah data yang dikumpulkan oleh lembaga pengumpul data. Data dalam penelitian ini yaitu data Kemiskinan, Pengangguran, Pertumbuhan Ekonomi dan Rata-rata Lama Sekolah Pulau Sulawesi tahun 2015-2019 yang diperoleh dari Badan Pusat Statistik.

\section{Definisi Operasional Variabel} Penelitian

Variabel penelitian adalah segala sesuatu yang berbentuk apa saja yang ditetapkan oleh peneliti untuk dipelajari sehingga diperoleh informasi tentang hal tersebut kemudian ditarik kesimpulannya (Sugiyono, 2012 :38).

1. Variabel Bebas (Independent Variable)

Variabel bebas adalah variabel yang mempengaruhi ataupun yang menyebabkan timbulnya atau berubahnya variabel terikat. Variabel bebas yang digunakan dalam penelitian ini adalah Pengangguran (X1), Pertumbuhan Ekonomi (X2), Rata-rata Lama Sekolah (X3).

\section{Variabel Terikat (Dependent Variable)}

Variabel terikat adalah variabel yang dipengaruhi karena adanya variabel bebas. Variabel bebas yang digunakan dalam penelitian ini adalah Kemiskinan (Y).

\begin{tabular}{|c|c|c|}
\hline \multicolumn{3}{|c|}{ Variabel Penelitian } \\
\hline Jenis Variabel & Devinisi Variabel & Satuan \\
\hline Kemiskinan & $\begin{array}{l}\text { Kemiskinan merupakan } \\
\text { sebuah kondisi yang } \\
\text { berada di bawah garis } \\
\text { standar kebutuhan } \\
\text { minimum, baik untuk } \\
\text { makanan maupun non- } \\
\text { makanan yang di sebut } \\
\text { garis kemiskinan (poverty } \\
\text { line) atau batas kemiskinan } \\
\text { (poverty trsehold). }\end{array}$ & Persen (\%) \\
\hline Pengangguran & $\begin{array}{l}\text { Pengangguran merupakan } \\
\text { suatu keadaan dimana } \\
\text { seseorang yang tergolong } \\
\text { dalam kategori angkatan } \\
\text { kerja (Labor Force) tidak } \\
\text { memiliki pekerjaan dan } \\
\text { secara aktif sedang } \\
\text { mencari pekerjaan (Nanga } \\
2005 \text {, h. 249). }\end{array}$ & Persen (\%) \\
\hline Pertumbuhan Ekonomi & $\begin{array}{l}\text { Merupakan pertumbuhan } \\
\text { produksi barang dan jasa } \\
\text { di suatu wilayah dalam } \\
\text { selang waktu tertentu. }\end{array}$ & Persen (\%) \\
\hline Rata-rata Lama Sekolah & $\begin{array}{l}\text { Indikator yang mengukur } \\
\text { derajat pendidikan dan } \\
\text { menggambarkan kualitas } \\
\text { sumber daya manusia dan } \\
\text { tingkat keberhasilan } \\
\text { pembangunan daerah. }\end{array}$ & Tahun \\
\hline
\end{tabular}

\section{Teknik Analisis Data}

Alat analisis yang digunakan dalam penelitian ini yaitu analisis linear berganda dengan perhitungan menggunakan data Panel. Analisis regresi berganda atau Multiple Regression merupakan persamaan regresi yang didalamnya terdapat dua atau lebih variabel dalam analisis. Tujuan dari analisis ini merupakan untuk mengetahui perameter estimasi dan berpengaruh sehingga, mampu menjelaskan hubungan antara variabel terikat dan variabel bebas. 
Adapun persamaan dari variabel yang disajikan pada tabel 3.1 diatas yaitu sebagai berikut:

$$
\mathrm{KEM}_{\mathrm{it}}=\beta 0+\beta_{1} \mathrm{PG}_{\mathrm{it}}+\beta_{2} \mathrm{PE}_{\mathrm{it}}+
$$

$\mathrm{RLS}_{\mathrm{it}}+\varepsilon \mathrm{it}$

Keterangan:

$\begin{array}{ll}\text { KEM } & =\text { Kemiskinan } \\ \beta_{0} & =\text { Konstanta atau bilangan } \\ \text { tetap } & \\ \text { PG } & =\text { Pengangguran (persen) } \\ \text { PE } & =\text { Pertumbuhan Ekonomi } \\ \text { (persen) } & \\ \text { RLS } & =\text { Rata-rata Lama Sekolah } \\ (\text { tahun) } & \\ \varepsilon t & =\text { Error term periode } \mathrm{t} \\ (\text { residual) } & \\ \beta_{1}, \beta_{2}, \beta_{3} & =\text { Koefisen regresi } \\ \mathrm{i} & =\text { Cross Section } \\ \mathrm{t} & =\text { Time Series }\end{array}$

Adapun beberapa metode yang digunakan untuk mengestimasi model regresi linear berganda yaitu:

a) Common Effect

Metode pendekatan ini tidak memperhatikan dimensi individu maupun waktu.

b) Fixed Effect

Metode ini mengamsumsikan adanya perbedaan intersep, karena tiap-tiap variable dalam model memiliki intersep yang tidak berubah sepanjang waktu meskipun intersep antara individu berbeda.

c) Random Effect

Model random effect mengakomodasi perbedaan karakteristik individu dan waktu pada error dari model. Model ini mengestimasi data panel dimana variable gangguan mungkin saling berhubungan antara waktu dan antara individu.

\section{Pembahasan}

Pulau Sulawesi merupakan salah satu pulau terbesar di Indonesia. Pulau Sulawesi terletas di sebelah timur Kalimantan, sebelah barat Kepulauan Maluku yang memiliki luas $\pm 174.600 \mathrm{~km}$ persegi. Secara astronomis, Pulau Sulawesi terletak di posisi $2^{\circ} 08^{\prime}$ LU serta $170^{\circ} 17^{\prime} B T$. Kondisi geografis Pulau Sulawesi dalam peta mencakup luas, batas laut dan darat, nama pantai, laut, dataran rendah, serta gunung. Ada tiga teluk yang membagi semenanjungsemenanjung diSulawesi yaitu Teluk Tomini, Tolo dan Bone. Secara administratif Pulau Sulawesi dibagi menjadi 6 provinsi, yaitu Sulawesi Selatan dengan ibukota Makassar, Sulawesi Barat dengan ibukota Mamuju, Sulawesi Tenggara, Sulawesi Tengah dengan ibukota Kendari, Sulawesi Utara dengan ibukota Manado dan Gorontalo dengan ibukota Kota Gorontalo.

Pulau Sulawesi memiliki potensi sumber daya alam yang melimpuh. Selain itu potensi wisata yang sangat banyak membuat para wisatawan memilih pulau Sulawesi. Salah satu potensi wisata yang banyak dikunjungi baik wisatawan asing maupun lokal yaitu di Kepulauan Togean yang sudah di kategorikan sebagai Taman Nasional Teluk Tomini. Potensi-potensi seperti ini yang harus terus dikembangkan agar perekonomian di masing-masing daerah di Pulau Sulawesi meningkat. 


\section{Kemiskinan}

Kemiskinan di pulau secara garis besar masih tinggi. Hal ini menunjukkan bahwa taraf hidup sebagian besar masyarakat di pulau Sulawesi masih rendah walaupun masih bisa ditopang oleh penduduk lain yang berkecukupan. Tingkat kemiskinan di pulau Sulawesi dapat diamati dalam grafik berikut.

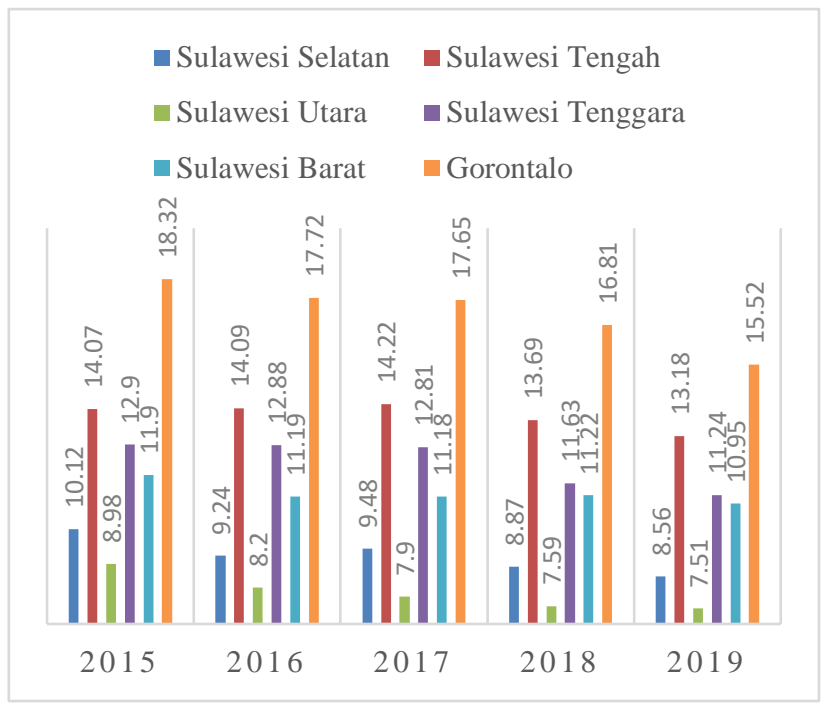

Gambar 4.1 (Sumber: BPS, 2020)

Data Penduduk Miskin Pulau Sulawesi 2015-2019

Berdasarkan grafik diatas terdapat perbedaan tingkat kemiskinan masing-masing daerah di pulau Sulawesi. Provinsi Gorontalo menjadi daerah yang memiliki tingkat kemiskinan tertinggi dibandingkan dengan provinsi lain. Sebaliknya Provinsi Sulawesi Utara menjadi provinsi yang paling kecil tingkat kemiskinannya. Rata-rata tingkat kemiskinan di pulau Sulawesi masih berada diatas dari lima persen. Ini tentunya menggambarkan bahwa secara keseluruhan angka kemiskinan di pulau Sulawesi masih tinggi.

\section{Pengangguran}

Tingkat pengangguran di pulau Sulawesi menggambarkan banyaknya penduduk angkatan kerja yang tidak memiliki pekerjaan ataupun tidak bekerja. Tingginya angka pengangguran disebabkan kurangnya lapangan pekerjaan maupun rendahnya kualitas sumber daya manusia yang ada sehingga tidak mampu bersaing dengan orang lain di dunia kerja. Berikut disajikan data pengangguran di pulau Sulawesi tahun 2015-2019.

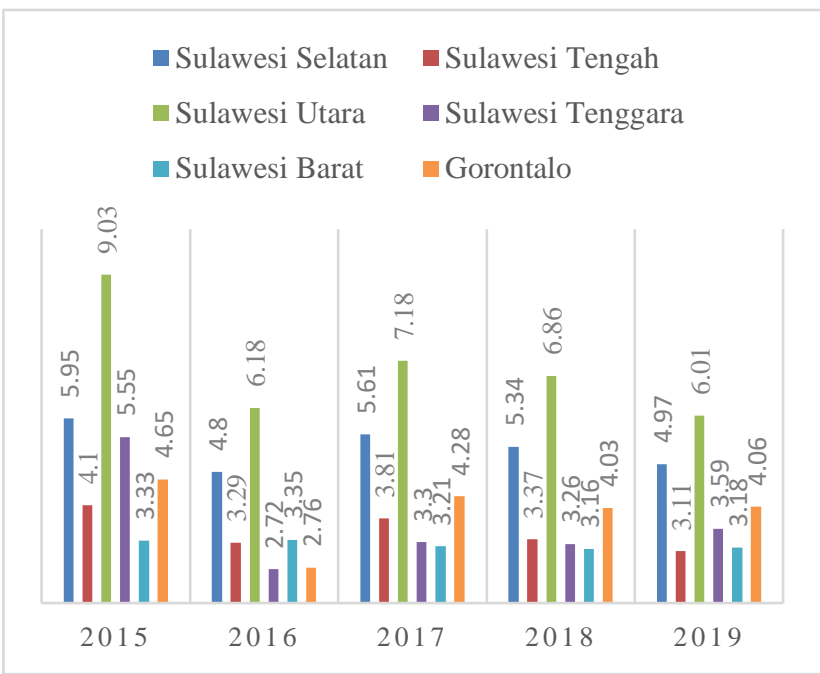

Gambar 4.2 (Sumber: BPS, 2020)

Data Tingkat Pengangguran Terbuka Provinsi Di Pulau Sulawesi 2015-2019

Dari Grafik diatas menggambarkan tingkat pengangguran di pulau Sulawesi relatin cukup rendah meskipun di beberapa daerah ada yang sangat tinggi. Seperti di Provinsi Sulawesi Utara merupakan daerah yang memiliki tingkat pengangguran tertinggi dibandingkan dengan daerah lain di pulau Sulawesi. Provinsi Sulawesi Selatan menyusul diurutan kedua tertinggi. Sebaliknya Provinsi Gorontalo mengalami penurunan tingkat pengangguran yang sangat signifikan di tahun 2016. 


\section{Pertumbuhan Ekonomi}

Pertumbuhan

ekonomi

menggambarkan baik tidaknya tingkat perekonomian suatu wilayah. Pertumbuhan ekonomi yang tinggi tidak serta merta memiliki kualitas yang baik begitupun sebaliknya. Berikut disajikan data pertumbuhan ekonomi Provinsi di Pulau Sulawesi.

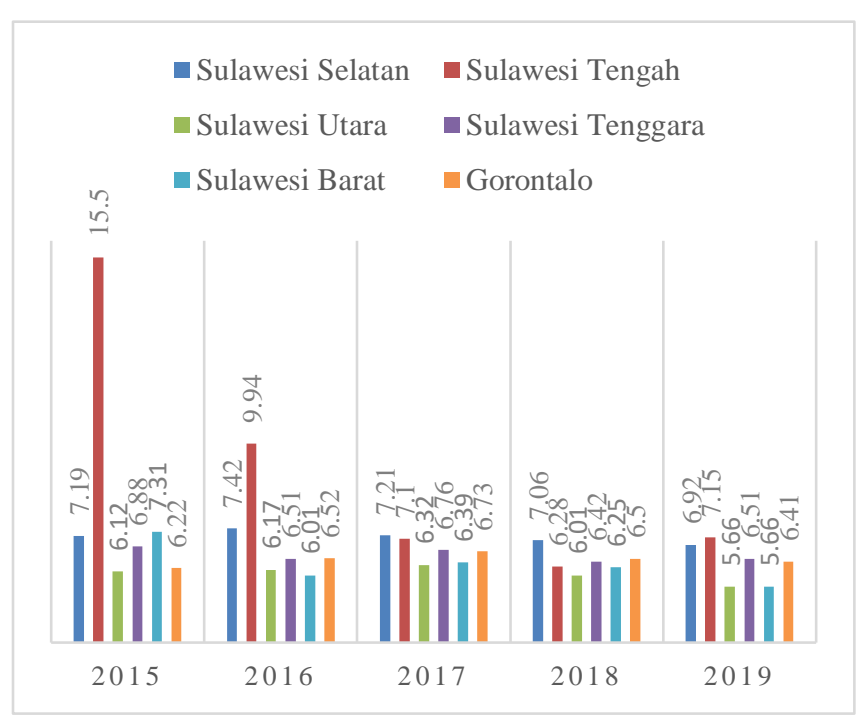

Gambar 4.3 (Sumber: BPS, 2020)

Data Pertumbuhan Ekonomi Provinsi

Di Pulau Sulawesi 2015-2019

Dari data diatas dapat dilihat bahwa Provinsi Sulawesi Tengah yang mengalami fluktuasi yang sangat signifikan di tahun 2015. Secara garis besar provinsi Sulawesi Tengah merupakan provinsi yang mengalami pertumbuhan ekonomi yang tinggi dibanding daerah yang lain. Sama halnya dengan provinsi Sulawesi Barat yang mengalami fluktuasi selama tujuh tahun berturut-turut.

\section{Rata-rata Lama Sekolah}

Rata-rata lama sekolah merupakan indikator pendidikan yang melihat lamanya seseorang bersekolah. Tingkat rata-rata lama sekolah pulau
Sulawesi dapat dilihat dalam grafik berikut.

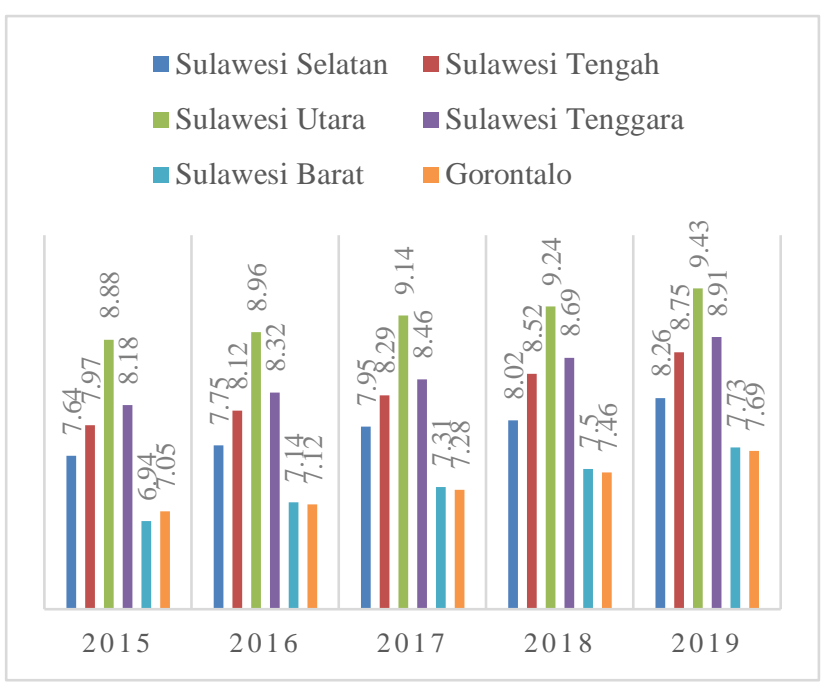

Gambar 4.4 (Sumber: Badan Pusat Statistik, 2020)

Data Rata-rata Lama Sekolah Provinsi Pulau Sulawesi 2015-2019

Secara keseluruhan dari data di atas rata-rata lama sekolah mengalami tren peningkatan setiap tahunnya disemua provinsi. Sulawesi Utara masih menjadi provinsi yang memiliki tingkat rata-rata lama sekolah dibandingkan dengan provinsi yang lain. Kemudian ada Provinsi Sulawesi Barat yang memiliki tingkat rata-rata lama sekolah terendah dan diikuti dengan Provinsi Gorontalo.

\section{Pengaruh Pengangguran Terhadap} Kemiskinan

Berdasarkan hasil analisis diperoleh hasil bahwa pengangguran berpengaruh positif namun tidak signifikan terhadap kemiskinan di pulau Sulawesi. Artinya setiap kenaikan angka pengangguran belum tentu dapat meningkatkan kemiskinan. Hal ini terjadi karena tidak selamanya pengangguran merupakan orang miskin. Kebutuhan hidup penganggur 
masih bisa ditanggulangi oleh keluarganya yang hidup berkecukupan. Belum lagi tingkat pengangguran penduduk di pulau Sulawesi didominasi oleh pengangguran terdidik khususnya di wilayah perkotaan. Sebaliknya di wilayah pedesaan tingkat pengangguran tidak terlalu tinggi namun kemiskinan masih sangat tinggi. Pendapatan masyarakat pedesaan yang rendah menyebabkan kemiskinan masih tinggi meskipun penduduknya tidak menganggur. Selain itu juga penduduk di wilayah pedesaan kebanyakan dari mereka berprofesi sebagai petani dan nelayan. meskipun demikian tingkat pendapatan yang diperoleh dari hasil pertanian maupun hasil tangkapan ikan masih sangat rendah, bahkan hanya bisa mencukupi kebutuhan harian. Dan juga hampir tidak ada alasan untuk orang miskin menganggur. Mau tidak mau mereka harus bekerja untuk dapat bertahan hidup. Dari beberapa fenomena inilah dapat menjawab ataupun dapat membuktikan bahwa tidak selamanya pengangguran berbanding lurus dengan kemiskinan.

Penelitian ini sejalan dengan penelitian yang dilakukan oleh Giovanni (2018) yang menyatakan bahwa variabel pengangguran tidak signifikan terhadap kemiskinan. Juga penelitian yang dilakukan oleh Zuhdiyati et.al, (2017) hasilnya yaitu pengangguran tidak berpengaruh signifikan terhadap kemiskinan. Namun bertolak belakang dengan penelitian yang dilakukan oleh Prastyo (2010) dimana menyatakan bahwa pengangguran berpengaruh positif dan signifikan terhadap kemiskinan. Sama halnya dengan penelitian yang dilakukan oleh Arianti (2017) yang menyatakan bahwa pengangguran berpengaruh positif terhadap kemiskinan.

\section{Pengaruh Pertumbuhan Ekonomi} Terhadap Kemiskinan

Dari hasil analisis yang telah diperoleh menunjukkan bahwa pertumbuhan ekonomi berpengaruh negatif dan signifikan terhadap kemiskinan di pulau Sulawesi. Artinya setiap peningkatan pertumbuhan ekonomi dapat menekan angka kemiskinan. Hal ini tentunya sangat jelas mengingat bahwa secara teoritis pertumbuhan ekonomi yang tinggi tentunya dapat mengurangi tingkat kemiskinan melalui pendapatan perkapita yang tinggi, lapangan pekerjaan yang semakin terbuka untuk menyerap tenaga kerja sehingga penduduk miskin akan lebih produktif lagi, produktivitas sektor pertanian yang meningkat, dan juga menjaga iklim investasi sehingga pertumbuhan ekonomi akan berkualitas atau pertumbuhan ekonomi inklusif. Akan tetapi dari data yang di rilis oleh Badan Pusat Statistik (BPS) masing-masing provinsi di pulau Sulawesi menunjukkan bahwa pertumbuhan ekonomi yang tiap tahunnya mengalami fluktuasi tidak dibarengi dengan turunnya angka kemiskinan yang signifikan. Masih ada beberapa daerah yang memiliki tingkat kemiskinan yang sangat tinggi contohnya seperti provinsi Gorontalo. Pendapatan perkapita yang rendah, dan perilaku konsumtif yang dimiliki oleh masyarakat menjadi penyebabnya.

Selain itu produktifitas sektor pertanian yang menjadi sektor unggulan juga nampaknya belum 
mampu memberikan kontribusi yang baik untuk dapat menekan angka kemiskinan. Mengingat sebagian besar masyarakat miskin berada di wilayah pedesaan yang umumnya berprofesi sebagai petani dan nelayan seharusnya dapat memanfaatkan sektor pertanian untuk dapat keluar dari zona kemiskinan. Akan tetapi penyerapan tenaga kerja di sektor pertanian dan juga hasil pertanian yang masih sangat kurang merupakan hal yang perlu diperhatikan agar kontribusi sektor pertanian bisa maksimal.

Penelitian ini sejalan dengan penelitian yang dilakukan oleh oleh Pangiuk (2018) yang menyatakan bahwa pertumbuhan ekonomi berpengaruh negatif dan signifikan terhadap kemiskinan. Akan tetapi bertolak belakang dengan penelitian yang dilakukan oleh Zuhdiyati et.al, (2017) yang menyatakan bahwa pertumbuhan ekonomi tidak berpengaruh signifikan terhadap kemiskinan. Sama halnya dengan penelitian yang dilaukan oleh Barika (2013) bahwa pertumbuhan ekonomi tidak signifikan terhadap kemiskinan.

\section{Pengaruh Rata-rata Lama Sekolah Terhadap Kemiskinan}

Dari hasil analisis yang diperoleh menunjukkan bahwa ratarata lama sekolah berpengaruh negatif dan signifikan terhadap kemiskinan. Artinya setiap kenaikan rata-rata lama sekolah akan diikuti dengan penurunan angka kemiskinan di pulau Sulawesi. Pendidikan dalam jangka panjang dapat mengurangi kemiskinan melalui peningkatan kualitas dan produktifitas penduduk. Semakin tinggi pendidikan seseorang, maka pengetahuan dan keahlian akan meningkat, sehingga dapat berpengaruh langsung terhadap produktifitas seseorang. Tingkat produktifitas penduduk yang baik akan mendorong tingkat kesejahteraan seseorang. Dan juga akan diikut dengan Peningkatan pendapatan dan tingkat konsumsi masyarakat, sehingga akan mengurangi tingkat kemiskinan penduduk. Dalam peningkatan pendidikan, pemerintah telah melakukan berbagai macam programprogram untuk memudahkan masyarakat mengakses pendidikan.

Masalah pendidikan tidak lagi menjadi masalah yang besar bagi penduduk miskin. Karena selain biaya yang dapat dijangkau bahkan ada program sekolah gratis dari pemerintah, sarana dan prasarana fasilitas penunjang pendidikan pun sudah tersedia dengan baik. Dengan memperbaiki kualitas hidup melalui pendidikan, masyarakat miskin kiranya dapat memanfaatkan fasilitas-fasilitas yang sudah tersedia ini.

Penelitian ini sejalan dengan penelitian yang dilakukan oleh Hadi (2019) dimana rata-rata lama sekolah berpengaruh signifikan terhadap kemiskinan. Begitu juga dengan penelitian yang dilakukan oleh Ratisyah (2019) yang hasilnya menunjukkan ratarata lama sekolah berpengaruh signifikan terhadap kemiskinan. Namun bertolak belakang dengan penelitian yang dilakukan oleh Sunarya (2018) dimana rata-rata lama sekolah tidak berpengaruh signifikan terhadap tingkat kemiskinan. 


\section{Penutup}

\section{Simpulan}

Sesuai hasil analisis dan pembahasan di atas maka dalam penelitian ini disimpulkan bahwa:

1. Pengangguran berpengaruh positif terhadap kemiskinan. Artinya setiap kenaikan angka pengangguran sebesar 1 persen akan diikuti dengan peningkatan angka kemiskinan sebesar 0,06. Namun pengangguran tidak berpengaruh signifikan terhadap kemiskinan provinsi di pulau Sulawesi.

2. Pertumbuhan Ekonomi berpengaruh negatif dan signifikan terhadap kemiskinan provinsi di pulau Sulawesi. Artinya setiap peningkatan pertumbuhan ekonomi sebesar 1 persen akan diikuti dengan penurunan tingkat kemiskinan sebesar 0,12.

3. Rata-rata Lama Sekolah berpengaruh negatif dan signifikan terhadap kemiskinan provinsi di pulau Sulawesi. Artinya setiap kenaikan rata-rata lama sekolah sebesar 1 persen akan diikuti dengan penurunan angka kemiskinan sebesar 2,35.

\section{Saran}

Adapun rekomendasi saran terkait hasil analisis diatas, penulis merekomendasikan beberapa hal yaitu:

1. Perlu adanya penyediaan lapangan kerja yang lebih banyak agar pengangguran bisa terserap dengan baik. Selain itu untuk mengentaskan kemiskinan kiranya pendapatan penduduk dari bekerja bisa ditingkat terutama upah minimum pekerja.
2. Kualitas pertumbuhan ekonomi harus ditopang oleh investasi. Diharapkan kepada pemerintah agar lebih meningkatkan investasi baik swasta maupun asing.

3. Perlu adanya peningkatan fasilitas penunjang pendidikan agar penduduk yang belum bersekolah nanti bisa mengenyam pendidikan yang layak. Program bantuan dana sekolah diperhatankan ataupun ditingkatkan dari segi jumlah bantuannya agar penduduk miskin yang ingin bersekolah bisa tercover sekaligus.

\section{Daftar Pustaka}

Arham, M. A. Hatu, R. 2020. Does Village Fund Transfer Address the Issue of Inequality and Poverty? A Lesson From Indonesia. The Journal of Asian Fiannce, Economics and Business. Vol. 7, No. 10. Hal 433442.

Arham, M. A. \& Dai, S. I. S. 2019. Analisis Pembiayaan, Kinerja Pendidikan, dan Pertumbuhan Ekonomi di Indonesia. Jurnal Economia, Vol.15, No. 2. Hal. 101-109.

Asrianti, A. (2017). Pengaruh Pertumbuhan Ekonomi, Pengangguran, dan Belanja Pemerintah terhadap Timgkat Kemiskinan di Indonesia PEriode 2007-2016. (Doctoral dissertation, Universitas Islam Negeri Alauddin Makassar).

Aziz, G. A., Rochaida, E. Warsilan, W. (2016). Faktor-faktor yang mempengaruhi kemiskinan di kabupaten kutai kartanegara. INOVASI: Jurnal Ekonomi 
Keuangan, dan Manajemen. Vol. 12,

No. 1, hal 29-48.

Badan Pusat Statistik 2020

Badan Pusat Statistik Provinsi di Pulau Sulawesi 2020.

Barika, 2013. Pengaruh Pertumbuhan Ekonomi, Pengeluaran pemerintah, Pengangguran Dan Inflasi Terhadap Tingkat Kemiskinan Di Provinsi Se Sumatera. Jurnal Ekonomi dan Perencanaan Pembangunan, Vol. 5, No. 3. Hal. 27-36

DP, M.K. (2017). Analisis Faktor-Faktor Penyebab Kemiskinan Di Kabupaten Musi Banyuasin (Studikasus Di Kecamatan Sungai Lilin). Jurnal Ilmiah Ekonomi Global Masa Kini. Vol. 8, No. 1, hal. 16-20 Gujarati, Damodar \& Dawn, Porter. 2012. Dasar-dasar Ekonometrika Buku 2. Jakarta: Salemba Empat.

Hadi, Abdul. 2019. Pengaruh Rata-rata Lama Sekolah Kabupaten/Kota Terhadap Persentase Penduduk Miskin Kabupaten/Kota di Provinsi Jawa Timur Tahun 2017. MediaTrend. Vol, 14, No. 2, Hal. 148-153

Iskandar, A., \& Subekan, A. (2016). Analisis Determinan Kemiskinan di Sulawesi Selatan (Determinant Analysis of Poverty in South Sulawesi). Jurnal Tata Kelola $\mathcal{E}$ Akuntabilitas Keuangan Negara. Hal 1-25

Laoh, O. E. H., Kapantow, G. H. (2019). Faktor-Faktor Yang Mempengaruhi Tingkat Kemiskinan di Sulawesi Utara. AGRI-SOSIOEKONOMI, Vol. 14, No. 3, hal 33-34.

Manoppo, J. J., Engka, D. S., Tumangkey, S. Y. (2018). Analisis Faktor-Faktor yang
Mempengaruhi Kemiskinan Di Kota Manado. EFFISIENSI, Vol. 18 , No.2

Pangiuk, A. 2018. Pengaruh Pertumbuhan Ekonomi Terhadap Penurunan Kemiskinan di Provinsi Jambi Tahun 2009-2013. Iltizam Journal Of Shariah Economic Research. Vol. 2, No. 2, hal 44-66

Prastyo, A. A., Edy Yusuf, E. Y. (2010). Analisis Faktor-Faktor Yang Mempengaruhi Tingkat Kemiskinan (Studi Kasus 35 Kabupaten/Kota Di Jawa Tengah Tahun 2003-2007. (Doctoral dissertation, Universitas Diponegoro)

Prasetyoningrum, A. K., Sukmawati, U. S. 2018. Analisis Pengaruh Indeks Pembangunan Manusia (IPM), Pertumbuhan Ekonomi dan Pengangguran Terhadap Kemiskinan di Indonesia. Equilibrium: Jurnal Ekonomi Syariah. Vol. 6, No. 2, hal 217-240.

Ratisyah. 2019. Pengaruh Pertumbuhan Ekonomi, Rata-rata Lama Sekolah, Dan Kepesertaan BPJS Terhadap Kemiskinan Kabupaten/Kota Di Provinsi Kalimantan Barat. Jurnal Pembangunan dan Pemerataan. Vol. 8 , No. 4, hal.

Rini, A. S., Sugiharti, L. (2016). FaktorFaktor Penentu Kemiskinan di Indonesia: Analisis Rumah Tangga. Jurnal Ilmu Ekonomi Terapan. Vol. 1, No.2. hal 17-33.

Rusdarti, R., Sebayang, L. K. (2013). Faktor-Faktor Yang Mempengaruhi Tingkat Kemiskinan di Provinsi Jawa Tengah. Jurnal Economia, Vol. 9, No.1, hal 1-9

Santoso, I.R., Olilingo, F.Z., (2019). Analysis Of Regional Economic 
Competitiveness of Gorontalo Province (Case Studi of Gorontalo Province Corn Commodity). Jambura Equilibrium Journal, Vo. 1, No. 1.

Sartika, C., Balaka, M.Y., Rumbia, W.A. (2016). Studi Faktor Faktor Penyebab Kemiskinan Masyarakat Desa Lohia Kecamatan Lohia Kabupaten Muna. Jurnal Ekonomi Uho. Vol. 1, No, 1.

Septianti, A. A., Mawardi, M., M., Rizki, M, A, K. (2016). Pengaruh Inflasi Dan Tingkat Pengangguran Terhadap Pertumbuhan Ekonomi Di Indonesia. I-Economics: A Research Journal On Islamic Economics. Vol. 2, No. 1, hal 50-65

Sirenden, E., Rafiy, M., Tamburaka, I. P. 2017. Analisis Faktor-Faktor Yang Mempengaruhi Jumlah Penduduk Miskin Di Provinsi Sulawesi Tenggara. JPEP (Jurnal Progres Ekonomi Pembangunan). Vol.2, No.1, hal 1-10.

Sirusa Badan Pusat Statistik 2020

Sugiyono. 2012. Metode Penelitian Kuantitatif, Kualitatif dan RED. Bandung: Alfabeta

Sukirno, Sadono. 2011. Ekonomi Pembangunan: Proses, Masalah, dan Dasar Kebijakan. Jakarta: Kencana.

Sukirno, Sadono. 2016. Makroekonomi Teori Pengantar Edisi 3 Cetakan 24. Jakarta: Rajawali Pers.

Sunarya, I. B. 2018. Analisis Pengaruh PDRB Per Kapita, Pendidikann, Kesehatan, Pengangguran, Dan Upah Minimum Terhadap Tingkat Kemiskinan Di Provinsi Jawa Tengah Tahun 2010-2015. Skripsi. Fakultas Ekonomi dan Bisnis Universitas Padjajaran.

Zuhdiyaty, N., Kaluge, D. (2017).

Analisis Faktor-Faktor Yang
Mempengaruhi Kemiskinan Di Indonesia Selama Lima Tahun Terakhir. Jurnal Ilmiah Bisnis dan Ekonomi Asia, Vol. 11, No. 2, hal 27-31 